\title{
DOI: https://doi.org/10.24297/jab.v12i0.8386
}

\section{Exposure Dose of Bacteria and Fungi in a Public Primary School in Beni Suef, Upper Egypt}

\author{
Mona Moustafa \\ Physics Department, Faculty of Sciences, Minia University, Minia, Egypt \\ Mona.mustafa@mu.edu.eg
}

\begin{abstract}
Potential health risk due to the exposure of bacteria and fungi is mainly related to the concentration of respirable airborne bacteria and fungi in indoor environments. Schools buildings represent an important category of indoor environments. This study aimed to evaluate the concentration and size distribution of bacteria and fungi in classrooms of a public primary school in Beni Suef, Egypt. In addition, the indoor exposure dose (IED) of bacteria and fungi were estimated for children and teachers. A six-stage Andersen impactor was used for collecting the bacterial and fungal particles. Indoor average concentration of bacteria was $1120 \pm 458 \mathrm{CFU} / \mathrm{m}^{3}$ while the corresponding fungal concentration was $291 \pm 89 \mathrm{CFU} / \mathrm{m}^{3}$. Bacterial level is almost twice the World Health Organization guideline value of $500 \mathrm{CFU} / \mathrm{m}^{3}$ while the fungal level is underestimated. Respirable fraction $(<5 \mu \mathrm{m})$, that can reach to the lower airways of the lung, of bacteria was $79 \%$ while the corresponding respirable fraction of fungi was $90 \%$ of the total concentration. The size distribution of bacteria was bimodal in nature and the fungal size distribution was unimodal with lower dispersion than bacteria. IED of bacteria was $211 \mathrm{CFU} / \mathrm{kg}$ and $70 \mathrm{CFU} / \mathrm{kg}$ for children and teachers, respectively. While the fungal IED was $55 \mathrm{CFU} / \mathrm{kg}$ and $18.2 \mathrm{CFU} / \mathrm{kg}$ for children and teachers, respectively.
\end{abstract}

Keywords: Indoor Exposure Dose; Respirable Fraction; Bacteria; Fungi; Size Distribution; Indoor Environment.

\section{Introduction}

Recently, several studies have investigated the concentration of biological particles, such as bacteria and fungi, in various indoor environments [1-5]. Biological particles contribute about $5-34 \%$ of the indoor air pollution [68]

Indoor level of biological particles depends on many physical and biological factors [9]. Indoor air has more pollution than the outdoor air $[10,11]$. In many indoor environments, fungi, bacteria and their fragments lie in the respirable size range $(<5 \mu \mathrm{m})$ that can penetrate deep in the human respiratory tract $[12,13]$.The risk of diseased related indoor air depends on the concentration and size distribution of biological particles in the indoor air $[14,15]$. Most people spend about $90 \%$ of their time in indoor environments therefore the quality of indoor air could significantly affect our general health [14]. Several adults and children spend about $30 \%$ of their time in school buildings and they need a high air quality environments $[6,16]$. School buildings represent an important category of indoor environments [17,18].

Several studies have investigated the Sick Building Syndrome (SBS) disease. SBS is characterized by several and non-specific syndromes observed in people in closed environments [19,20]. World Health Organization (WHO) has defined SBS as an increase in frequency in the occupants of non-industrial buildings of not specific acute symptoms, such as nausea, fatigue, headache, irritation of eyes, nose and throat, that improve when leaving the building [21]. Children are more affected by the pollution than adults due to their higher activities and their less mature immune system [22,23]. Earlier studies in schools and children environments have revealed a negative effect of health on children [24,25]. The health effects of biological particles are not only depend on their concentrations but also to their size distribution. The size of biological particles determine the site of deposition in the human lung [26]. Indoor exposure dose of inhaled microorganisms for children and adults depends on the microorganisms concentration and the individual's body mass [27]. Therefore, the objectives of this study 
were to investigate the concentration and size distribution of bacteria and fungi in a classrooms of a public primary school in Beni Suef (Egypt) and to estimate the inhaled dose of indoor bacteria and fungi for both children and teachers.

\section{Materials and Methods}

The study was performed during summer season in classrooms of a public primary school in Ehnasia city, $20 \mathrm{Km}$ to the west of Beni Suef Governorate, $28.9^{\circ} \mathrm{N}$ and $30.6^{\circ} \mathrm{E}$, as this school provides summer courses during the sampling time of summer season. Map of Beni Suef is illustrated in Figure 1. The average age of the children was 7 years old. The classroom has an area of $20 \mathrm{~m}^{2}$.

During sampling, the temperature ranged from 32 to $36^{\circ} \mathrm{C}$ with an average value of $34{ }^{\circ} \mathrm{C}$. The average relative humidity recorded was $43 \%$. Sampling was performed during the teaching hours under normal ventilation where all windows and doors are kept open and there were a mechanical ventilations as well.

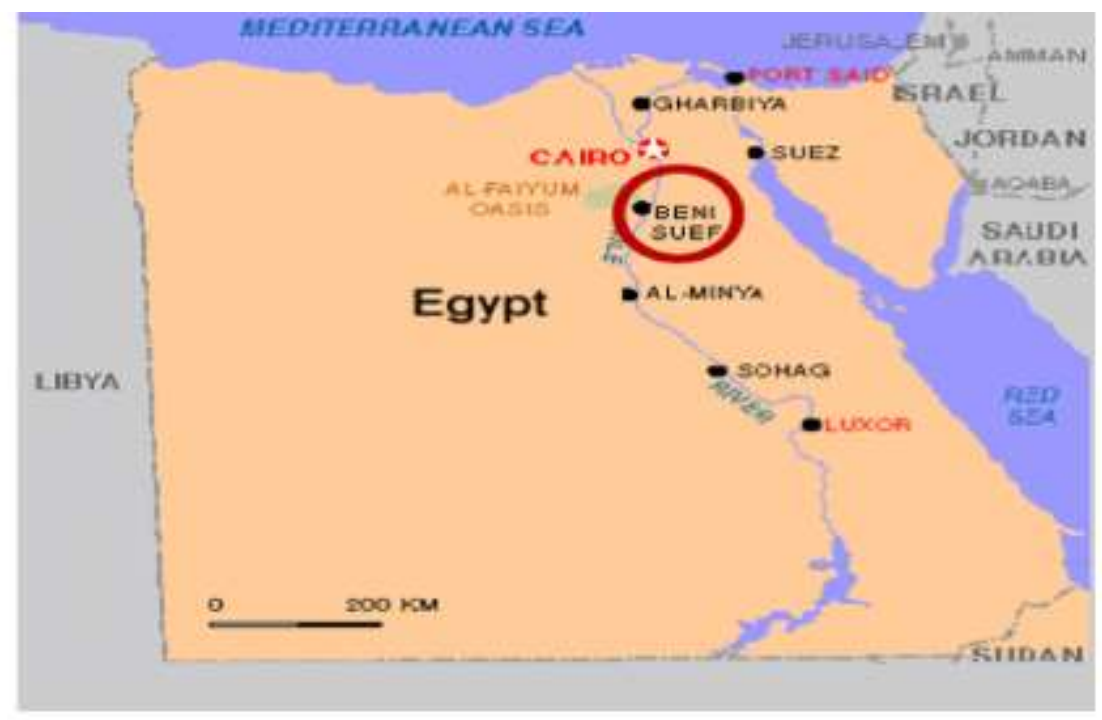

Figure 1. Beni Suef map

A six- stage Andersen impactor was used for collecting the bacteria and fungi. The impactor operates at a constant flow rate of $28.3 \mathrm{~L} / \mathrm{min}$. The collected particles are classified according to the aerodynamic cut-size diameters of the impactor $(>7.0 \mu \mathrm{m}, 4.7-7.0 \mu \mathrm{m}, 3.3-4.7 \mu \mathrm{m}, 2.1-3.3 \mu \mathrm{m}, 1.1-2.1$ and $0.65-1.1 \mu \mathrm{m})$. The impactor was located in the center of the classroom at height of about one meter from the ground to stimulate the breathing zone.

Nutrient Agar (NA) was used as a collecting media for bacterial particles. For collecting fungal particles, Malt extract agar (2\% MEA), which is a broad spectrum medium for fungi, was used. A volume not less than $27 \mathrm{ml}$ of culture medium was placed in a removable glass Perti dish where plastic ones should not be used because the static charge generated reduces the collection efficiency. The Petri dish was inserted in the impactor. The sampling time ranged from 10 to $20 \mathrm{~min}$ for each run to avoid overestimation of the particle colonies. The samples were incubated at room temperature for 2 to 7 days. Colonies on each plate were counted. The concentration of biological particles was estimated as colony forming unit per cubic meter of air $\left(\mathrm{CFU} / \mathrm{m}^{3}\right)$ by the following equation:

$$
C=\frac{N}{V . t} \ldots \ldots \ldots . . C F U / \mathrm{m}^{3}
$$


Where

$\mathrm{C}$ is the microorganism concentration

$\mathrm{N}$ is the number of colonies on each impactor stage

$V$ is the flow rate of the impactor in $\mathrm{m}^{3} / \mathrm{h}$

$\mathrm{t}$ is the sampling time in $\mathrm{h}$.

\section{Results and Discussion}

\section{Total and respirable concentrations of bacteria and fungi}

Total and respirable concentrations of bacteria and fungi in the classrooms are listed in Table 1. Average bacterial concentration was $1120 \pm 458 \mathrm{CFU} / \mathrm{m}^{3}$ while the corresponding average fungal concentration was $291 \pm 89$ $\mathrm{CFU} / \mathrm{m}^{3}$. The higher level of bacteria than fungal level may be attributed to the dependence of the bacterial growth on the occupants activity [28]. While the fungal concentration is affected by the outdoor sources more than the indoor $[29,30]$. The mean concentration of bacteria was nearly twice the World Health Organization guide line (WHO) value of $500 \mathrm{CFU} / \mathrm{m}^{3}$ [31] while the mean concentration of fungi is lower than this limit.

Table 1. Mean bacterial and fungal concentrations $\left(\mathrm{CFU} / \mathrm{m}^{3}\right)$, respirable fractions (\%) and size distribution parameters (median aerodynamic diameters, $D_{p}(\mu \mathrm{m})$ and geometric standard deviation, GSD)

\begin{tabular}{|c|c|c|c|c|}
\hline Microorganism & $\begin{array}{c}\text { Concentration } \pm \text { SD } \\
\left(\mathrm{CFU} / \mathrm{m}^{3}\right)\end{array}$ & $\begin{array}{c}\text { Respirable fraction } \\
(\%)\end{array}$ & $\mathrm{D}_{\mathrm{p}}(\mu \mathrm{m})$ & $\mathrm{GSD}$ \\
\hline Bacteria & $1120 \pm 458$ & 79 & 2.6 & 2.2 \\
\hline Fungi & $291 \pm 89$ & 90 & 2.9 & 1.6 \\
\hline
\end{tabular}

The potential health risk due to the exposure of bacterial and fungal particles is mainly related to the concentration of respirable airborne bacteria and fungi [28]. The respirable fraction of bacteria and fungi is defined as the sum of the concentrations collected on the stage $3(3.3-4.7 \mu \mathrm{m})$, stage $4(2.1-3.3 \mu \mathrm{m})$, stage 5 $(1.1-2.1 \mu \mathrm{m})$ and stage $6(0.65-1.1 \mu \mathrm{m})$ of viable Andersen impactor with respect to the total concentration of bacteria and fungi on all the six-stages of the impactor [32].

Concentration fractions \% of bacteria and fungi are summarized in Table 1 and are illustrated in Figure 2 and Figure 3, respectively. Repirable fraction of bacterial particles was $79 \%$ while the corresponding respirable fraction of fungi was $90 \%$ in the classrooms. In comparison with other studies, The respirable fractions of airborne bacteria and fungi in a nursery school were found in the range 63-80\% [28]. In public building, the respiratory fractions were $50 \%$ and $70 \%$ for bacteria and fungi, respectively [33]. In American homes, the respiratory fractions were $55 \%$ and $80 \%$ for bacteria and fungi, respectively [34]. While in Taiwnese homes, the respirable fraction were $70-85 \%$ for fungi [35].

I can conclude for an important result: although the total concentration of bacteria in indoor is higher than the total concentration of fungi, the present results indicate that the respirable fraction of fungi was higher than the respirable fraction of bacteria. Therefore, it is not only important to assess the total concentration of airborne microorganisms but also it is important to assess their respirable fractions due to the positive relation between the concentration of the respirable fraction of microorganism and the health effects [32]. 


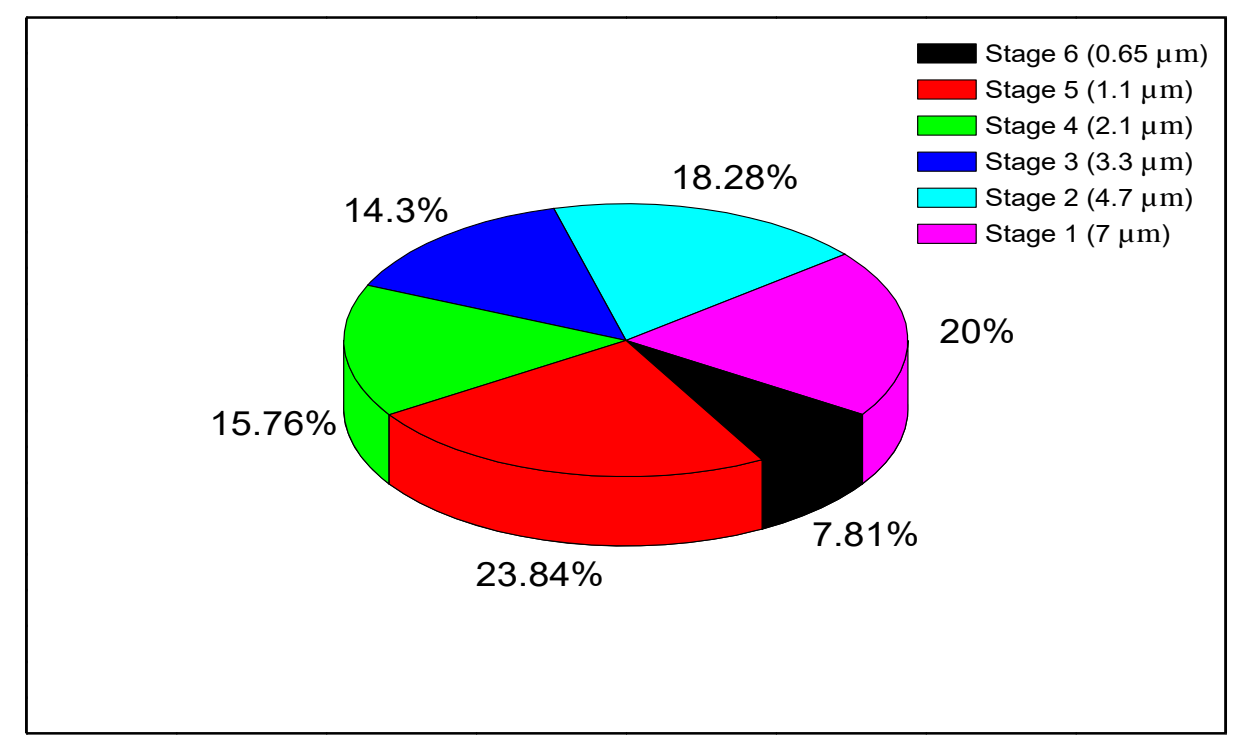

Figure 2. Concentration $\%$ of bacteria with particle size in classroom

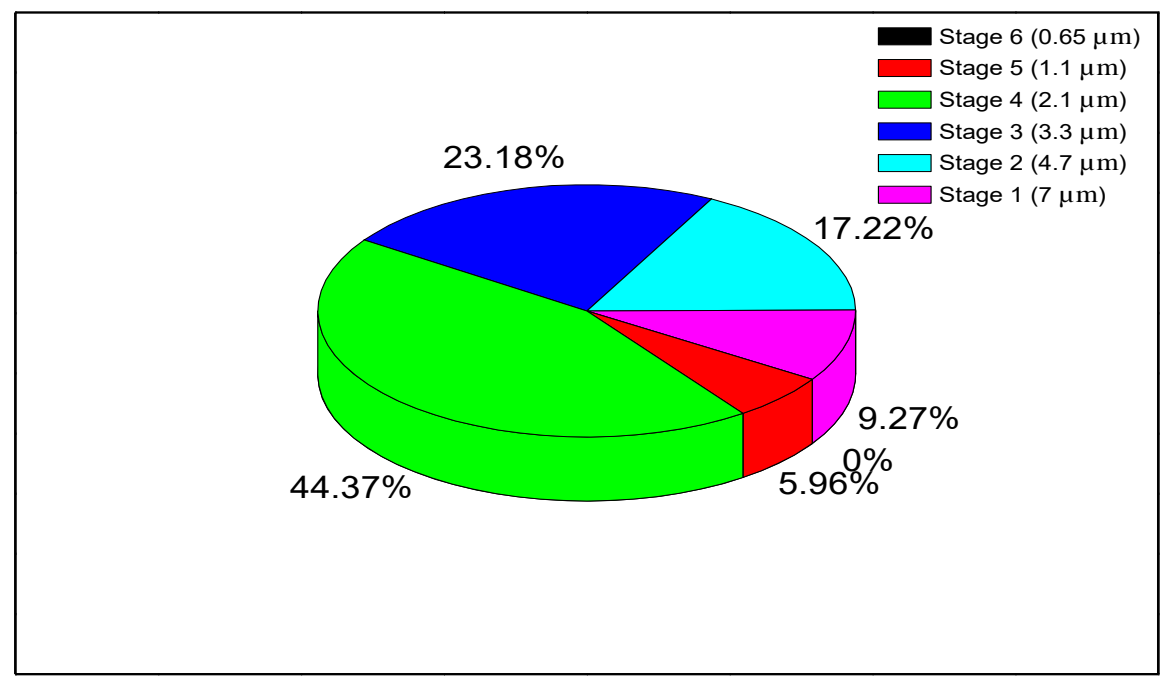

Figure 3. Concentration \% of fungi with particle size in classroom

\section{Size distribution of bacteria and fungi}

Size distributions of bacteria and fungi are illustrated in Figure 4 and Figure 5, respectively. The size distribution parameters, median aerodynamic diameter, $\operatorname{MAD}\left(D_{p}\right)$ and geometric standard deviation GSD are summarized in Table 1. MAD is defined as the diameter at 50\% cumulative fractions and GSD of the size distribution is defined as the diameter at $84 \%$ cumulative number divided by the diameter obtained at $50 \%$ [36].

Figure 4 shows the bimodal distribution of bacteria corresponding to the accumulation mode (particles with diameter $<2.5 \mu \mathrm{m}$ ) and coarse mode (particles with diameter $>2.5 \mu \mathrm{m}$ ). The MAD of bacterial distribution was $2.6 \mu \mathrm{m}$ with a GSD of 2.2. A high concentration was observed at size range $(1.1-2.1 \mu \mathrm{m})$ with $23.84 \%$ from the 
total concentration (Figure 2 ) and $20 \%$ at the size range $(4.7-7.0 \mu \mathrm{m})$. Figure 5 shows the unimodal distribution of fungi corresponding to the accumulation mode. MAD of fungal distribution was $2.9 \mu \mathrm{m}$ with a GSD of 1.6. Fungal distribution has a high concentration at size range (2.1-3.3 $\mu \mathrm{m})$ with $44.37 \%$ from the total concentration (Figure 3). Similar distribution of bacteria and fungi were investigated by others [28, 37].

It is observed that the dispersion of bacterial particles $(G S D=2.2)$ is higher than the dispersion of fungal particles $(G S D=1.6)$. Similar dispersion of bacteria and fungi was found by Meklin et al., [37].

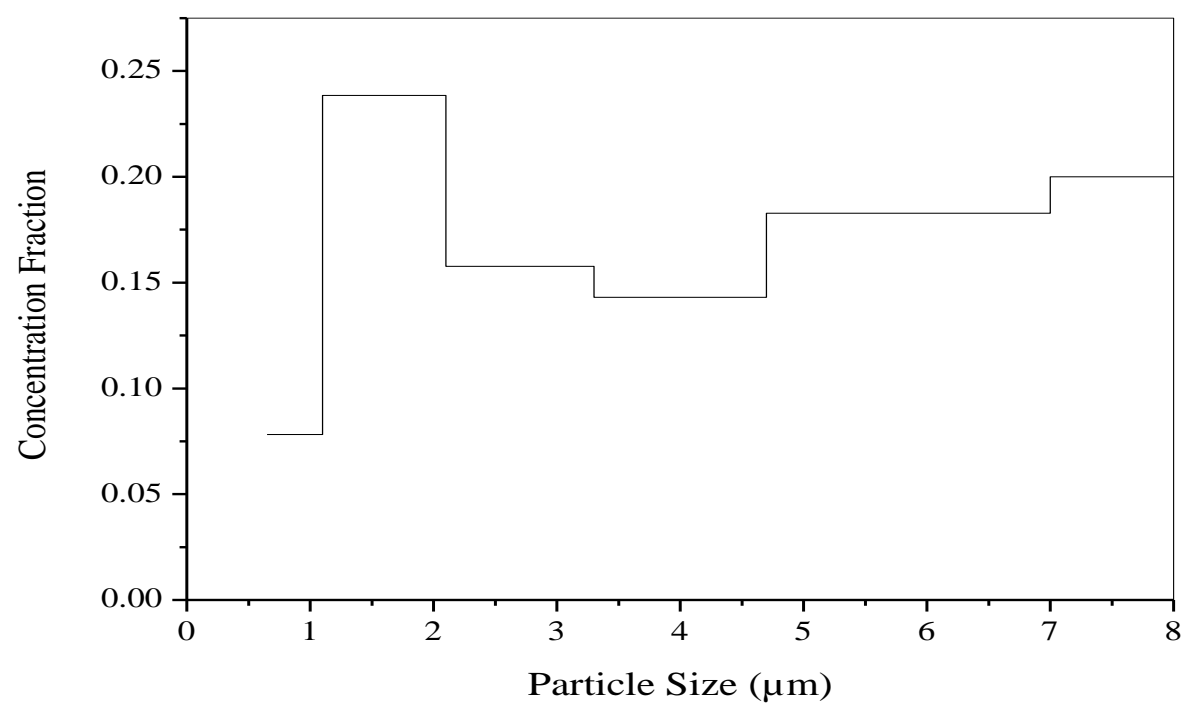

Figure 4. Size distribution of bacteria in classroom

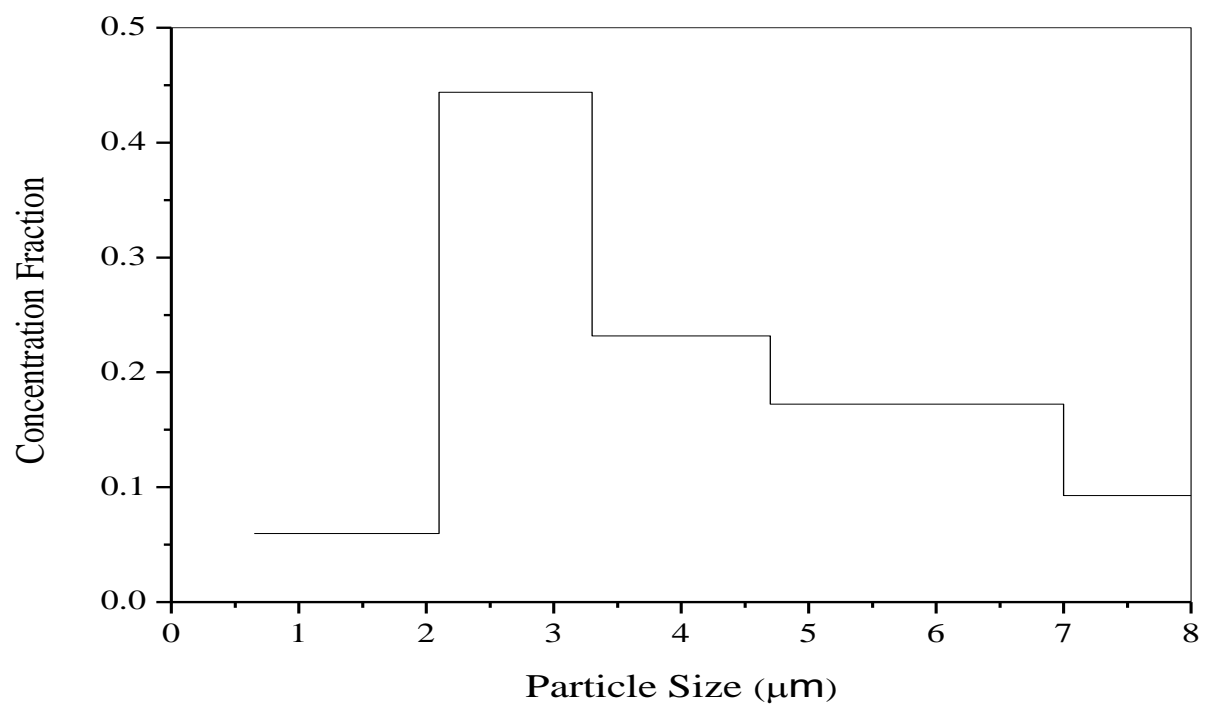

Figure 5. Size distribution of fungi in classroom 


\section{Indoor Exposure Dose (IED) of bacteria and fungi}

The assessment of infection risk depends not only on the number of inhaled microbes but also on the individual's body mass [22]. According to this assumption, the doses of bacteria and fungi per mean body weight were calculated [21]. The IED has been calculated on the basis of the US Environmental Protection Agency factors $[40,41]$.

Depending on the measured microorganism concentrations, physical activity of the individuals and the exposure time, the IED was estimated based on the following equation:

$$
\text { IED }=\frac{\text { C. IR. IEF }}{\text { BW }}
$$

Where, IED is the indoor exposure dose (CFU/Kg);

$\mathrm{C}$ is the concentration of bacteria and fungi $\left(\mathrm{CFU} / \mathrm{m}^{3}\right)$;

IR is the inhalation rate coefficient, characteristic for the physical activity $\left(\mathrm{m}^{3} / \mathrm{h}\right)$;

IEF is the indoor exposure fraction that represents the time spent over a day in the indoor environment (h) and

BW is the mean body weight $(\mathrm{Kg})$.

Assuming light physical activity, IR is $0.66 \mathrm{~m}^{3} / \mathrm{h}$ for children and $0.78 \mathrm{~m}^{3} / \mathrm{h}$ for teachers, the average of IEF if $8 \mathrm{~h}$. Average body weight (BW) is $28 \mathrm{~kg}$ for children and $100 \mathrm{~kg}$ for teachers as recorded in the school (Table 2).

The mean indoor exposure dose (IED) of bacteria and fungi for children and adults are summarizes in Table 2 . The indoor exposure dose of bacteria (IED) was $211 \mathrm{CFU} / \mathrm{kg}$ for children and $70 \mathrm{CFU} / \mathrm{kg}$ for teachers.

Table 2. Indoor Exposure Fraction, IEF (h), Inhalation Rate, IR $\left(\mathrm{m}^{3} / \mathrm{h}\right)$ at light physical activity, Body Weight, BW $(\mathrm{kg})$ of children and teachers and Indoor Exposure Dose, IED $(\mathrm{CFU} / \mathrm{kg})$ of bacteria and fungi for children and teachers

\begin{tabular}{|c|c|c|c|cc|}
\hline Occupant & IR $\left(\mathrm{m}^{3} / \mathrm{h}\right)$ & IEF $(\mathrm{h})$ & BW( $\mathrm{kg})$ & \multicolumn{2}{|c|}{ IED (CFU/kg) } \\
& & & & Bacteria & Fungi \\
\hline Children & 0.66 & 8 & 28 & 211 & 55 \\
Teachers & 0.78 & 8 & 100 & 70 & 18.2 \\
\hline
\end{tabular}

While the corresponding IED of fungi $55 \mathrm{CFU} / \mathrm{kg}$ and $18.2 \mathrm{CFU} / \mathrm{kg}$ for children and teachers, respectively.

The higher activity of children, which means a higher inhalation, and less mature immune systems than the adults $[22,23]$ may explain the higher dose inhaled by children. 
It is found that the bacterial IED was higher than the fungal IED which may be attributed to the higher concentration of bacteria than of fungi in the classroom. These results agree with Bragoszewska et al. [38] results where the bacterial IED was higher also than the fungal IED.

In comparison with others results [38,39], it was found that the present calculated IED is lower than the IED obtained by others; where $302.3 \mathrm{CFU} / \mathrm{kg}$ mean IED of bacteria was calculated by Bragoszewska et al. [39] and $175.4 \mathrm{CFU} / \mathrm{kg}$ by Bragoszewska [42]. The reason of this discrepancy is due to the higher Egyptian body weight, in this study, compared to others.

\section{Conclusions}

Schools are an important category of indoor environments and children have sensitive immune systems let them more vulnerable to microbes contamination than adults. A higher bacterial level was investigated in the school than the recommended limit. The indoor exposure dose (IED) of bacteria is higher than fungi. Children have higher dose than adults. Therefore, it is recommended more environmental studies and more public health programs in school buildings for achieving a health and high air quality indoor environment.

\section{Acknowledgments}

The author gratefully acknowledge the support by the Faculty of Science, Minia University. Acknowledgment is also conducted to the staff of the school due to their help throughout this work.

\section{References}

1. Pegas, P.N., Evtyugina, M.G., Alves, C.A., Nunes, T., Cerqueira, M., Franchi, M., Pio, C., Almeida, S.M., Freitas, M.C. Outdoor/indoor air quality in primary schools in Lisbon: A preliminary study, Quim Nova. 2010; (33): 1145- 49.

2. Aydogdu, H., Asan, A ., Tatman, O.M. Indoor and outdoor airborne bacteria in child day - care centers in Edirn city (Turky), seasonal distribution and influence of meteorological factors, Environ Monit Assess. 2010; (164): 53- 6.

3. Armadans-Gil L, Rodríguez-Garrido V, Campins-Martí M, Gil-Cuestaa J., Vaqué-Rafart J. Particle counting and microbiological air sampling: results of the simultaneous use of both procedures in different types of hospital rooms, Enferm Infecc Microbiol Clin. 2013; (31): 217- 21.

4. Grisoli, P., Albertoni, M., Rodolfi, M. Application of airborne microorganisms indexes in offices, gyms and libraries, Appl Sci. 2019; (9), 1101. http:// doi:10.3390/app9061101.

5. Andualem, Z., Gizaw, Z., Bogale, L., Dange, H. Indoor bacterial load and its correlation to physical indoor air quality parameters in public primary schools, Multidisci Resp Med. 2019;(14), 2. https://doi.org/10.1186/s40248-018-0167

6. Samson, E., Ihongbe, J.C., Okeleke,O., Hi , E., Phillips Adeyemi, O. Microbiological assessment of indoor air quality of some selected private primary schools in Ilishan-Remo, Ogun state, Nigeria, 2017; (3), 24549142.

7. Fekadu, H.S., Amanuel, E., Aklilu, D.F. Quantitative assessment of bio-aerosols contamination in indoor air of university dormitory rooms, Int J Health Sci. 2015; (3), 249-56.

8. Zemichael, G., Mulat, G., Chalachew, Y. High bacterial load of indoor air in hospital wards: the case of University of Gondar teaching hospital, Northwest Ethiopia, Multidiscip Respir Med. 2016; (11), 24. doi: 10.1186/s40248-016-0061-4. 
9. Seyed, M.H., Mahnaz, N., Kazuo, S., Koichi, M. Assessment of airborne particles in indoor environments: Applicability of particle counting for prediction of bioaerosol concentrations, Aerosol and air qual Res. 2016; (16), 1910-2016.

10. Kotzias, D. Indoor air and human exposure assessment-Needs and approaches, Exp Toxicol Pathol. 2005; (57), 5-7.

11. Yassin, M.F. Almouqatea S. Assessment of airborne bacteria and fungi in an indoor and outdoor environment, Int J Environ Sci Technol. 2010; (7), 535- 44.

12. Jozef, S.P., Kyaw Tha Paw, U., Danuta, O.L., Agnieszka, W. and Krzysztof, U. Bacterial and fungal aerosols in indoor environment in upper Silesia, Poland, Atmos Environ. 2000; (34), 3833-42.

13. Bipasha, G., Himanshu, .L, Rajesh, K., Naba, H., Arun, S., Vinod, K.J. Estimation of bioaerosol in indoor environment in the university library of Delhi, Sustain, Environ Res. 2013; (23), 199-207.

14. Fekadu, H.S., Melaku, M.A. Microbiological quality of indoor air in university libraries, Asian Pac J of trop biomed. 2014; (4), S312-7.

15. Moustafa, M. Size-resolved concentration of bacteria and fungi in indoor and outdoor environments, Int J Biophys. 2017; (4), 53-9.

16. Mohan, K., Madhan, N., Ramprasad, S., Maruthi, Y.A. Microbiological air quality ofindoors in primary and secondary schools of Visakhapatnam, India. Int J Curr Microbiol App Sci. 2014; (8), 880-7.

17. Daisey, J.M., Angell, W. J., Apte, M.G. Indoor air quality, ventilation and health symptoms in schools: an analysis of existing information, Indoor Air 2003; (1), 53-64.

18. Nascimento, P. P., Alves, C., Guennadievna, E.M., Nunes, T. Indoor air quality in elementary schools of Lisbon in Spring, Environ Geochem Health 2010; (33), 455-68.

19. Wolff, $\mathrm{CH}$. Innate immunity and the pathogenicity of inhaled microbial particles, Int J Biol Sci. 2011; (7), 261-68.

20. Qian, J., Hospodsky, D., Yamamoto, N., Nazaroff, W.W., Peccia, J. Size-resolved emission rates of airborne bacteria and fungi in an occupied classroom, Indoor Air 2012; (22), 339-51.

21. World Health Organization. Indoor Air Pollutants: Exposure and Health Effects; Report on a WHO Meeting, EURO Reports and Studies 1983; no. 78; WHO Regional Office for Europe: Copenhagen: Denmark.

22. Yoon, C., Lee, K., Park, D. Indoor air quality differences between urban and rural preschools in Korea, Environ Sci Pollut Res. 2011; (18), 333-45.

23. Demirel, G., Ozden, O., Dogeroglu, T., Gaga, E.O. Personal exposure of primary school children to Btex, $\mathrm{NO}_{2}$ and ozone in Eskisehir, Turky: Relationship with indoor/outdoor concentrations risk assessment, Sci Total Environ. 2014; (1), 473-74, 537-48.

24. Bornehag, C., Sundell, J., Sigsgaard, T. Dampness in buildings and health (DBH): Report from an ongoing epidemiological investigation on the association between indoor environmental factors and health effects among children in Sweden, Indoor Air, 2004; (14), 59-66. 
25. Zuraimi, M.S., Tham, K.W. Indoor air quality and its determinants in tropical child care centers, Atmos Environ. 2008; (42), 2225-39.

26. Bragoszewska, E., Mainka, A., Pastuszka, J.S. (2017) Concentration and size distribution of culturable bacteria in ambient air during spring and winter in Gliwice: A typical urban area, Atmos. 2017; (8), 239. DOI: $10.3390 /$ atmos8120239

27. Bragoszewska, E., Mainka, A., Pastuszka, J.S. Bacterial aerosols in an urban nursery school in Gliwice, Poland: A case study, Aerobiol. 2016a; (32), 469-80.

28. Bragoszewska, E., Mainka, A., Pastuszka, J.S. Bacterial and fungal aerosols in rural nursery schools in Southern Poland, Atmos. 2016b; (7), 142. doi:10.3390/atmos7110142.

29. Hospodsky, D., Yamamoto, N., Nazaroff, W.W., Miller, D., Gorthala, S., Peccia, J. Characterizing airborne fungal and bacterial concentrations and emission rates in six occupied children's classrooms, Indoor air. 2015; (25), 641-52.

30. Shin, S-K., Kim, J., Ha, S-M., Oh, H-S., Chun, J., Sohn, J., Yi, H. Metagenomic Insights into the Bioaerosols in the Indoor and Outdoor Environments of Childcare Facilities, PLoS ONE. 2015; (5), e0126960. https://doi.org/10.1371/journal.pone.0126960

31. World Health Organization. Indoor air quality: Biological contaminant. Copenhagen: WHO regional publications, 1990; European series No. 31.

32. Kim, K.Y., Kim, C. N. Airborne microbiological characteristics in public buildings of Korea, Build Environ. 2007; (42), 2188-96.

33. Pastuszka, J.S., Kyaw, T. P. U., Danuta, O.L., Walzlo, A., Ulfig, K. Bacterial and fungal aerosols in indoor environment in upper Silesia, Poland. Atmos Environ. 2000; (34), 3833-42.

34. DeKoster, J.A., Thorne, P.S. (1995) Bioaerosol concentrations in noncompliant. Complaint and intervention homes in the Midwest, Amerc Indust Hygie Assoc J. 1995; (56), 576- 80.

35. Li, C. S., Kuo, Y. M. Microbiological indoor air quality in subtropical areas, Environ Inter. 1993; (19), 23339.

36. Hinds, W. C. Aerosol technology, properties, behavior, and measurement of airborne particles. 1999; 2nd edn. New York: Wiley.

37. Meklin, T., Reponen, T., Toivola, M., Koponen, V., Husman, T., Hyvarinen, A., Nevalainen, A. Size distributions of airborne microbes in moisture-damaged and reference school buildings of two construction types, Atmos Environ. 2002; (36), 6031-39.

38. Bragoszewska, E., Mainka, A., Pastuszka, J. Bacterial and fungal aerosols in rural nursery schools in southern Poland, Atmos. 2016c; (7), 142. Doi: 10.3390/atmos7110142.

39. Bragoszewska, E., Mainka, A ., Pastuszka, J. Bacterial aerosols in an urban nursery school in Gliwice, Poland: A case study, Aerobiol. 2016d; (32), 469-80.

40. US Environmental Protection Agency. Child-specific Exposure factors Handbook. Environmental Protection Agency. 2002; Washington, DC, USA. 
41. Johnson-Restrepo, B., Kannan, K. An assessment of sources and pathways of human exposure to polybrominated diphenyl ethers in United states, Chemos. 2005; (76), 542-48.

42. Bragoszewska, E. Bacterial aerosol occurring in atmospheric air in Gliwice and it is share of the total human exposure to the bacteria absorbed by inhalation. 2014, Ph. D. Thesis. Silesian university of technology, Gliwice, Poland. 